\title{
PENERAPAN LEAN MANUFACTURING UNTUK MENGURANGI WASTE PADA PRODUKSI ABSORBENT
}

\author{
Agung Ravizar, Rosihin Rosihin \\ Program Studi Teknik Industri, Fakultas Teknik, Universitas Serang Raya \\ Email: agungravizar@yahoo.com; rosihin.hasbullah@wilmar.co.id
}

\begin{abstract}
Abstrak - Penelitian ini bertujuan untuk mengurangi waste yang terjadi pada setiap workstation dan berdampak pada peningkatan produktifitas dan mengurangi biaya produksi yang akibatkan oleh waste yang terjadi pada saat produksi. Data yang digunakan untuk penelitian ini adalah data kuantitatif yang didapat dengan cara observasi langsung ke departemen terkait mengenai masalah identifikasi waste yang terjadi. Data yang diambil dari observasi sebanyak 30 kali pengambilan data dan data historis yang digunakan dari Januari 2016 sampai dengan Juni 2017. Dengan menggunakan metode value stream mapping pada lean manufacturing dapat diketahui terjadi 5 jenis waste dari seven waste yang ada. Kelima waste tersebut adalah unnecessary motion, waiting, reject, transportation dan inpropriate process. Dari hasil implementasi value stream mapping yang dilakukan terjadi pengurangan waste pada tiap workstation dengan total pengurangan waste yang terjadi sebesar 66,97 Ton/tahun atau 18,6\% pada waste gel dan 88,8 ton/tahun atau 19,3\% pada waste powder dan terjadi pengurangan waktu proses changeover selama 45 menit atau 12,16\% dari total waktu changeover sebelum improvement selain itu juga terjadi peningkatan kecepatan proses produksi selama 2 menit 47 detik atau sebesar 4,52\% dari lead time proses produksi sebelumnya yaitu 61 menit 34 detik menjadi 58 menit 47 detik.
\end{abstract}

Kata kunci: Lean Manufacturing; VSM; Waste

\begin{abstract}
This study aims to reduce the waste that occurs on each workstation and has an impact on increasing productivity and reducing production costs caused by waste that occurs during production. The data used for this study is quantitative data obtained by direct observation to the relevant departments regarding the problem of identifying waste that occurs - data taken from observations as much as 30 times the collection of data and historical data used from January 2016 to June 2017. By using the value stream mapping method on lean manufacturing, it can be seen that there are five types of waste from the existing seven waste. The five wastes are unnecessary motion, waiting, reject, transportation and in-process processes. From the results of the value stream mapping carried out a reduction in waste on each workstation with a total reduction of waste that occurs at 66.97 tons / year or $18.6 \%$ on waste gel and 88.8 tons / year or $19.3 \%$ at waste powder and there was a reduction in the changeover process for 45 minutes or $12.16 \%$ of the total changeover time before the improvement. Also, there was also an increase in the production process speed of 2 minutes 47 seconds or $4.52 \%$ from the lead time of the previous production process, 61 minutes 34 seconds to 58 minutes 47 seconds.
\end{abstract}

Keywords: Lean Manufacturing; VSM; Waste

\section{PENDAHULUAN}

Perkembangan industri dan teknologi dalam era globalisasi sekarang ini semakin pesat, ditandai dengan tingkat persaingan antar perusahaan semakin meningkat dan ketat. Keadaan ini menyebabkan perusahaan harus mampu mempertahankan usaha yang dikelolanya. Untuk dapat mempertahankan dan terus meningkatkan keuntungan, perlu adanya perhitungan dan perencanaan yang cukup untuk dapat terus bersaing dan berkembang. Banyak faktor yang mempengaruhi hasil keuntungan suatu perusahaan. Salah satunya adalah terdapatnya waste atau pemborosan pada saat proses produksi. Lean Manufacturing adalah metode yang cocok digunakan oleh perusahaan untuk mengidentifikasi tingkat pemborosan atau waste sehingga mampu menekan atau bahkan bisa mengurangi kegiatan atau aktivitas yang tidak bernilai tambah (non value added activity) (Gaspersz, 2007).

Untuk memenuhi permintaan dan 
kepuasan konsumen, perusahaan ini selalu berusaha meningkatkan produksinya dengan tepat waktu. Namun dalam pembuatan produk tersebut terjadi beberapa jenis pemborosan. Pemborosan jenis reject seperti kontaminasi pada produk absorben, jenis waiting seperti terlalu lamanya pekerja dalam menyelesaikan masalah yang sering terjadi sehingga mengakibatkan banyaknya waktu yang terbuang, jenis unnecessary inventory seperti adanya penumpukan material yang membuat material tersebut mengalami kerusakan. Proses produksi perusahaan yang tidak efektif dan efisien dapat menyebabkan produksi tidak lancar, seperti halnya penumpunkan bahan baku pada lantai produksi yang disebut bottleneck. Terjadinya bottleneck salah satunya dapat disebabkan oleh ketidak seimbangan waktu proses-proses di lantai produksi yang mana ada proses yang membutuhkan waktu yang sangat lama. Penyebab lamanya waktu proses tersebut karena ke-tidak efisien-an dalam mengelola sumber daya yang ada. Untuk itu, faktor-faktor yang ikut berkontribusi di dalamnya, seperti sumber daya manusia, mesin, material, dan lain sebagainya harus senantiasa dievaluasi apakah masih relevan dengan kondisi bisnis yang dijalankan atau perlu dilakukan revisi/perbaikan (Kodradi, Soewignyo, \& Rusdiansyah 2008). Pemborosan - pemborosan tersebut membuat kerugian pada perusahaan. Sehingga tidak tercapainya target dari operation ratio/ target produktivitas pada tahun 2016 yaitu sebesar $95.3 \%$ dari $97 \%$ target produksi. Sedangkan waste yang dihasilkan pada proses produksi sangat besar yaitu sebesar 460 ton waste powder dan 360 ton waste gel dalam satu tahun sebagaimana tertera pada grafik berikut:

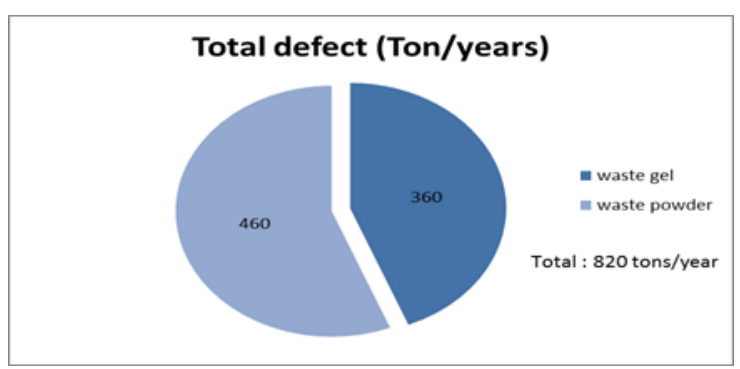

Gambar 1. Waste Reject tahun 2016

Berdasarkan permasalahan yang dihadapi maka perusahaan membutuhkan penyelesaian untuk mengurangi pemborosan yang terjadi di lantai produksi dengan melihat tujuh pemborosan (waste) yaitu kelebihan produksi (overproduction), proses yang tidak perlu (inappropriate process), menunggu (waiting), persediaan yang tidak perlu (unnecessary inventory), transportasi (transportation), gerakan yang tidak perlu (unnecesary motion) dan kecacatan (reject). Proses efisiensi yang dilakukan hendaknya sesuai dengan kemampuan dan sumber daya yang ada pada perusahaan. Karena itu perlu pendakatan yang relative sederhana dan terstruktur dengan baik agar mudah dipahami yaitu pendekatan lean manufacturing. Teknik-teknik dalam lean manufacturing membantu perusahaan menjadi lebih kompetitif, terkhusus dalam hal pengurangan waste (pemborosan) dalam proses operasi mereka. Lean manufacturing didefinisikan sebagai sebai pereduksi dari waste (pemborosan) dalam segala bentuk atau kondisi dengan memaksimalkan aktivitas yang bernilai tambah (value added) (Forrester, 1995).

Berdasarkan uraian diatas maka penelitian difokuskan untuk menemukan solusi atas pemasalahan tersebut. Solusi yang diusulkan yaitu menggunakan metode sekaligus tools dari lean manufacturing untuk mengurangi pemborosan (waste) adalah Value Stream Mapping.

\section{METODE PENELITIAN}

Penelitian ini menggunakan metode Value stream Mapping (VSM) dalam proses analisis. Value stream Mapping (VSM) merupakan salah satu dari lean tools yang terbukti ampuh untuk menghilangkan waste (non-added value), memetaan aliran material dan infomasi dalam sistem produksi. Value stream Mapping diperkenalkan pertama kali oleh Moki Rother dan John Shook dalam bukunya "Learning To See" yang menjelaskan cara menggunakan pemetaan aliran proses added dan non value added di lantai produksi untuk mencapai kondisi lean manufacturing. Value stream Mapping lahir dari konsep Toyota Production Sistem (TPS), dimana pada TPS dikenal dengan "Material and Information Flow Mapping (MIFC)".

Value stream Mapping adalah sebuah metode visual untuk memetakan jalur produksi dari sebuah produk yang di dalamnya termasuk material dan informasi dari masing-masing stasiun kerja. Value stream Mapping ini dapat dijadikan titik awal bagi perusahaan untuk mengenali pemborosan dan mengidentifikasi penyebabnya. Menggunakan value stream berarti memulai dengan gambaran besar dalam menyelesaikan permasalahan bukan hanya pada proses-proses tunggal dan melakukan peningkatan secara menyeluruh dan bukan hanya pada proses-proses tertentu saja. Value stream Mapping tidak hanya mengvisualisasikan aliran material dalam sistem produksi, namun 
juga mengvisualisasikan aliran informasi perintah produksi pada supplay chain secara keseluruhan. Aliran informasi ini dapat digunakan untuk melihat apakah terjadi stagnasi informasi atau tidak pada sebuah sistem produksi. Tujuan dari Value stream Mapping adalah mengidentifikasi semua waste pada aliran produksi dan berusaha untuk mengeliminasi waste tersebut (Rother and Shook, 2003).

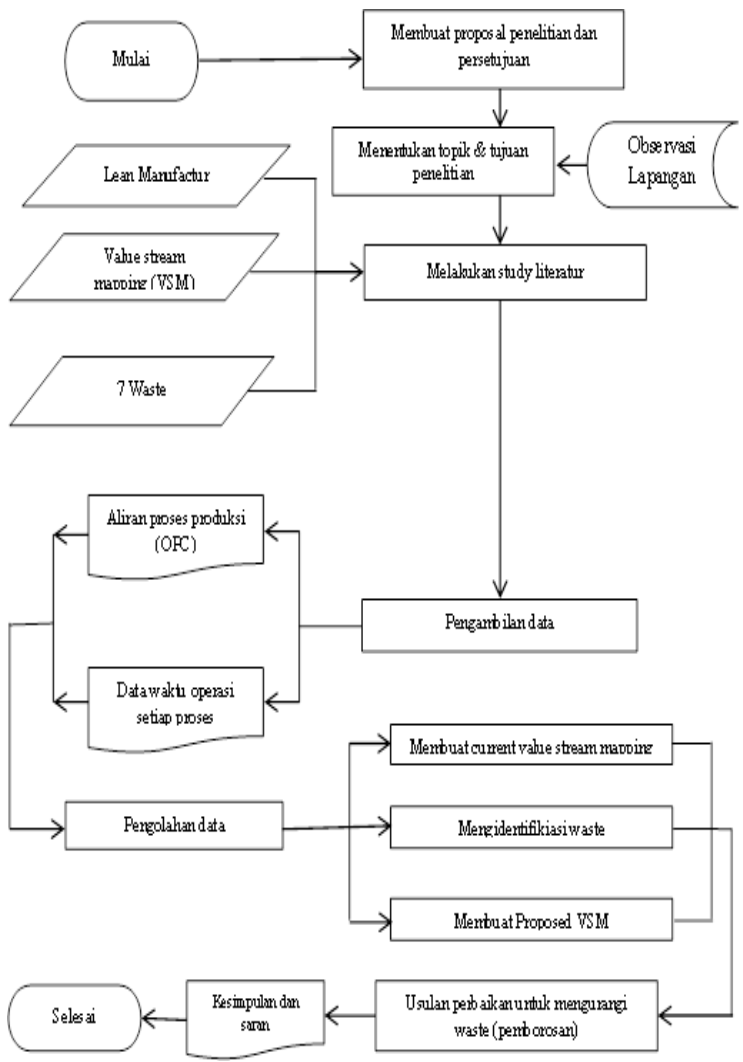

Gambar 2. Diagram Alir Penelitian

\section{HASIL DAN PEMBAHASAN}

Data awal yang digunakan untuk melakukan penelitian ini adalah data Changeover time pada masing-masing Workstation (Tabel 1) dan peta proses operasi dalam pembuatan Super Absorbent Polymer (SAP) (Gambar 3)

Tabel 1. Data Changeover Time

\begin{tabular}{lll}
\hline No & Workstation & Menit \\
\hline 1 & Neutralization & 0 \\
2 & Pollymerization & 60 \\
3 & Drying & 135 \\
4 & Pulverization & 130 \\
5 & Classification & 45 \\
6 & Filling & 30 \\
\hline
\end{tabular}

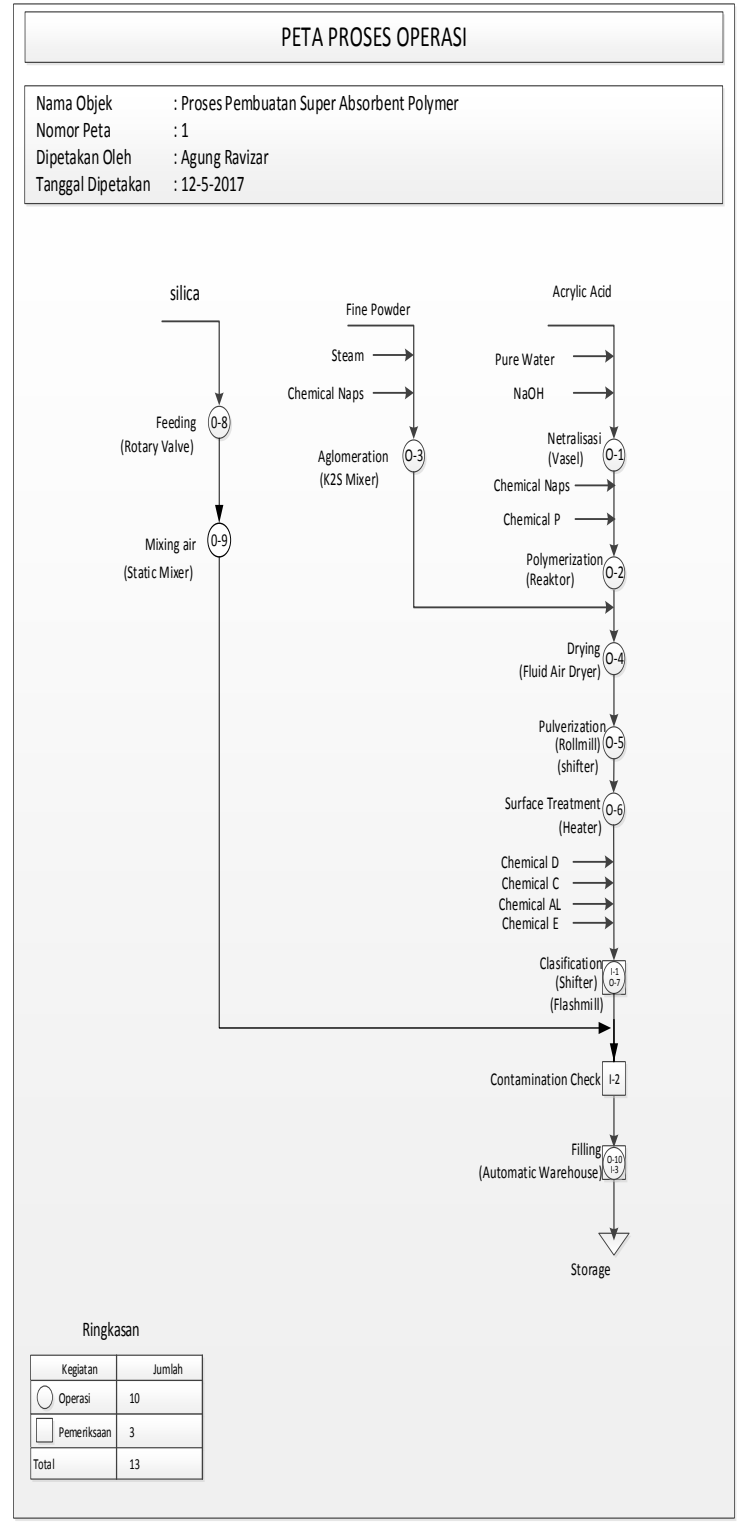

Gambar 3. Operation Proses Chart

Dalam menentukan waktu normal diperlukan nilai ratting, dimana nilai rating digunakan untuk menyesuaikan ketidakwajaran operator yang sedang diukur dalam menyelesaikan pekerjaannya. Hal ini terjadi karena kurangnya kesungguhan pekerja, bekerja terlalu cepat, terlalu lambat, keterampilan buruh yang bervariasi, kondisi area Workstation, dan pengaruh lainnya yang berimbas pada hasil kerja operator. Pada tabel 2 di bawah ini merupakan ringkasan hasil perhitungan waktu normal dan waktu baku. Dimana waktu baku terbesar terjadi pada Workstation Classification dan waktu baku terkecil pada Workstation Neutralization. 
Tabel 2. Ringkasan Perhitungan Waktu

\begin{tabular}{|c|c|c|c|c|c|c|}
\hline Proses & Neutralization & Pollymerization & Drying & Pulverization & Classification & Filling \\
\hline Rata-rata & 372 & 434 & 434 & 574 & 535 & 466 \\
\hline Ratting & 1.05 & 1 & 1.02 & 1 & 0.98 & 1.02 \\
\hline Allowance & $11 \%$ & $12 \%$ & $23 \%$ & $27 \%$ & $37 \%$ & $17 \%$ \\
\hline Jumlahobservasi & 30 & 30 & 30 & 30 & 30 & 30 \\
\hline Waktu normal & 390.1 & 434.4 & 443.1 & 573.5 & 523.9 & 475.5 \\
\hline Waktu Baku & 438.3 & 493.6 & 575.4 & 785.6 & 831.6 & 572.9 \\
\hline
\end{tabular}

Pada Produk perusahaan terdapat 2 keluarga produk, dimana keluarga produk tersebut adalah Type-W dan Type-L. Pada penelitian ini akan fokus di keluarga produk Type-W, dimana pada keluarga produk Type-W terdapat 6 item produk yang diproduksi yaitu $W$ 211, W-343, W-349, W-101, W-103, WS-349. Keluarga produk Type-W melayani produk container bag $1000 \mathrm{Kg}$ dan $500 \mathrm{Kg}$ serta paper bag $20 \mathrm{Kg}$. Sedangkan penelitian ini akan fokus di satu produk yaitu W-343. Pemilihan produk ini sudah berdasarkan hasil diskusi dengan pihak manajemen.

Sedangkan demand produk W-343 adalah 32 Ton/Shift. Dimana dalam setiap ton produk tersebut dimasukan dalam 1 container bag. Sehingga target unit yang dibutuhkan dalam keluarga produk Type-W berjumlah 32 unit pallet dalam satu shift.

Takt time berfungsi sebagai acuan seberapa lama proses produksi pada sebuah Workstation yang seharusnya dilakukan atau biasa disebut waktu ideal proses produksi untuk menyelesaikan tugas satu produk (Rother and Shook,1999). Penggunaan takt time sangat berguna untuk mengetahui bagaimana kondisi aktual kecepatan proses produksi yang sedang berjalan. Pada umumnya takt time akan dibandingkan dengan cycle time, dimana jika cycle time dibawah takt time maka dapat disimpulkan bahwa banyak waktu menganggur pada proses tersebut atau kecepatan proses terlalu cepat, sedangkan jika cycle time diatas takt time maka dapat disimpulkan proses tersebut overload atau beban kerja pada proses tersebut melebihi yang seharusnya. Rumus Takt time berasal dari:

$\mathrm{T}=\mathrm{Ta} / \mathrm{D}$

T : Takt Time

Ta : Time Available (Waktu kerja bersih yang tersedia)

D : Demand (Permintaan Pelanggan)

Time Available didapat dengan mengurangi waktu dalam 1 shift dengan waktu istirahat. Pada Perusahaan waktu yang tersedia dalam 1 shift adalah 8 jam (480 menit), sedangkan total waktu istirahat adalah 60 menit. Sehingga dalam satu shift Time Available sebesar 420 menit $=25.200$ detik. Takt time pada Type-W berbentuk container bag sehingga takt time container bag adalah:

Takt time Container Bag $=\frac{25200 \text { detik }}{32}=$

787.5 detik atau 13.1 menit/ container bag.

Maksud dari Takt time Container Bag sebesar 13.1 menit/container bag menunjukan bahwa waktu ideal pada Workstation drying, pulverization, classification dan filling menyelesaikan pekerjaannya setiap 13.1 menit/container bag.

Inventory dan WIP berfungsi sebagai buffer (penyangga) pada system produksi, dengan adanya inventory dan WIP maka diharapkan kegiatan produksi bisa berjalan secara smooth flow, tidak ada idle pada proses selanjutnya (Tabel 3)

Tabel 3. WIP di PT. Nippon Shokubai Indonesia

\begin{tabular}{lll}
\hline Jenis & Tempat & Jumlah \\
\hline Raw material & Netralization & 8 Ton \\
WIP & Classification & 4 container \\
Finish & Filling & bag \\
Goods & & bag container \\
\hline
\end{tabular}

Setelah semua data didapatkan dan diolah sesuai metode lean manufacturing, langkah selanjutnya yaitu penggambaran current value stream mapping. Pada current value stream mapping ini ada 3 komponen utama yaitu:

a) komponen time line waktu value added dan non value added.

b) komponen aliran material dari bahan baku sampai barang jadi

c) komponen informasi perintah produksi dan informasi supplay chain pada supplier atau customer.

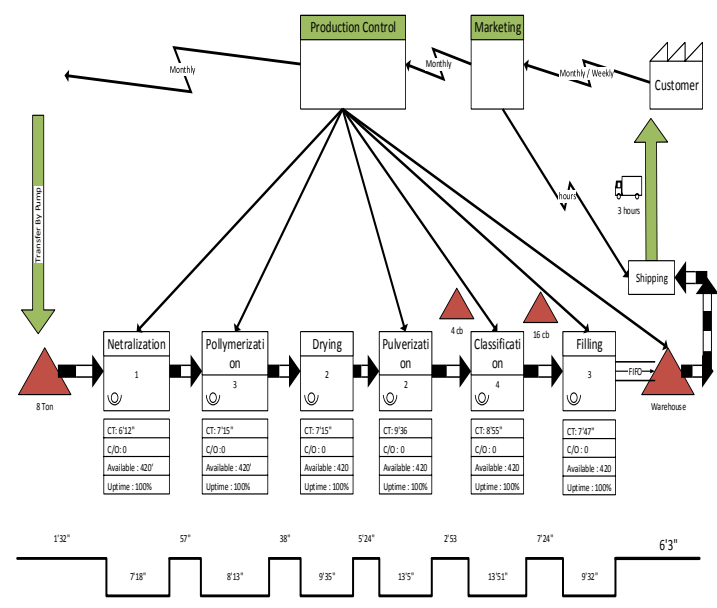

Gambar 4. Current Value stream mapping Produk Type W-343 
Terlihat bahwa supplier mengirimkan raw material dengan menggunakan pompa karena lokasi kedua perusahaan berdekatan, sedangkan finish goods diambil di area shipping setiap 3 jam sekali. Lead time material dari barang masuk ke area Netralization sampai barang jadi pada current value stream mapping di perusahaan ini selama 1 jam 26,41 menit dan lead time pada proses produksi yaitu selama 61 menit 34 detik.

Berikut Tabel-Tabel Aktifitas pekerjaan pada tiap Workstation yang divisualisasikan dalam aliran proses value added (VA), necessary but non value added (NNVA) dan non value added (NVA).

Tabel 4. Aktifitas dalam Workstation polymerization

\begin{tabular}{|c|l|c|c|c|c|c|}
\hline Mesin & \multicolumn{1}{|c|}{ Aktivitas } & VA & NNVA & NVA & $\begin{array}{c}\text { Normal } \\
\text { operation }\end{array}$ & $\begin{array}{c}\text { Changeover } \\
\text { time }\end{array}$ \\
\hline \multirow{2}{*}{ Reaktor } & Merubah fase liquid ke solid & $V$ & & & V & \\
\hline & Mengendalian polymer & $V$ & & & $v$ & \\
\hline \multirow{2}{*}{ Gel Cutter } & Memotongan polymer & & $V$ & & $v$ & \\
\hline & $\begin{array}{l}\text { Membersihkan gel kecil yang } \\
\text { menumpuk }\end{array}$ & & & $v$ & $v$ & $v$ \\
\hline Crusher & $\begin{array}{l}\text { melumat gel menjadi ukuran } \\
\text { yang lebih kecil }\end{array}$ & $v$ & & & $v$ & \\
\hline
\end{tabular}

Waste: Unnecessary Motion \& Waiting, Reject

Tabel 5. Aktifitas dalam Workstation Drying

\begin{tabular}{|l|l|l|l|l|c|c|}
\hline Mesin & \multicolumn{1}{|c|}{ Aktivitas } & VA & NNVA & NVA & $\begin{array}{c}\text { Normal } \\
\text { operation }\end{array}$ & $\begin{array}{c}\text { Changeover } \\
\text { time }\end{array}$ \\
\hline \multirow{2}{*}{ Swing Feeder } & $\begin{array}{l}\text { mendistribusikan gel ke } \\
\text { dalam dryer }\end{array}$ & $v$ & & & $v$ & \\
\hline & $\begin{array}{l}\text { membersihkan gel yang } \\
\text { menumpuk }\end{array}$ & & & $v$ & & $v$ \\
\hline & $\begin{array}{l}\text { menyeting jarak pembersih } \\
\text { swiper }\end{array}$ & & $v$ & & & $v$ \\
\hline Dryer & $\begin{array}{l}\text { mengeringkan gel menjadi } \\
\text { powder }\end{array}$ & $v$ & & & $v$ & \\
\hline $\begin{array}{l}\text { Mechanical } \\
\text { conveyor }\end{array}$ & $\begin{array}{l}\text { mengirim powder ke } \\
\text { Workstation selanjutnya }\end{array}$ & & $v$ & & $v$ & \\
\hline \\
Waste: Mnnecessary Motion \\
Unnect,
\end{tabular}

Tabel 5. Aktifitas dalam Workstation Pulverization

\begin{tabular}{|l|l|c|c|c|c|c|}
\hline Mesin & \multicolumn{1}{|c|}{ Aktivitas } & VA & NNVA & NVA & $\begin{array}{c}\text { Normal } \\
\text { operation }\end{array}$ & $\begin{array}{c}\text { Changeover } \\
\text { time }\end{array}$ \\
\hline Pin mill & $\begin{array}{l}\text { Melumat powder menjadi } \\
\text { lebihkecil }\end{array}$ & V & & & $v$ & \\
\hline Rollmill & $\begin{array}{l}\text { Memperhalus ukuran power } \\
\text { sesuain spesifikasi }\end{array}$ & $v$ & & & $v$ & \\
\hline Shifter & $\begin{array}{l}\text { Memisahkan jenis powder } \\
\text { berdasarkan ukuran }\end{array}$ & $v$ & & & $v$ & \\
\hline Heater & $\begin{array}{l}\text { memanaskan powder untuk } \\
\text { mengkontol kualitas powder }\end{array}$ & $v$ & & & $v$ & \\
\hline
\end{tabular}

Waste: Menunggu (Waiting).
Tabel 6. Aktifitas dalam Workstation Classification

\begin{tabular}{|l|l|c|c|c|c|c|}
\hline \multicolumn{1}{|c|}{ Mesin } & \multicolumn{1}{|c|}{ Aktivitas } & VA & NNVA & NVA & $\begin{array}{c}\text { Normal } \\
\text { operation }\end{array}$ & $\begin{array}{c}\text { Changeover } \\
\text { time }\end{array}$ \\
\hline Shifter & $\begin{array}{l}\text { Memisahkan jenis powder } \\
\text { berdasarkan ukuran }\end{array}$ & $v$ & & & $v$ & \\
\hline $\begin{array}{l}\text { Magnet } \\
\text { separator }\end{array}$ & $\begin{array}{l}\text { Memisahkan metal yang } \\
\text { terbawa ke dalam proses } \\
\text { dengan sistem magnet stains }\end{array}$ & $v$ & & & $v$ & \\
\hline samping Nozle & $\begin{array}{l}\text { mengecek powder secara } \\
\text { visual }\end{array}$ & & $v$ & & $v$ & \\
\hline Forlift & menngangkut silica & & $v$ & & & \\
\hline Feeder & $\begin{array}{l}\text { mendistribusikan silica kje } \\
\text { dalam proses }\end{array}$ & $v$ & & & & \\
\hline
\end{tabular}

Waste: Overprocess (Proses Yang Berlebihan), Transportasi

Tabel 7. Aktifitas dalam Workstation filling

\begin{tabular}{|c|c|c|c|c|c|c|}
\hline Mesin & Aktivitas & VA & NNVA & NVA & $\begin{array}{c}\text { Normal } \\
\text { operation }\end{array}$ & $\begin{array}{c}\text { Changeover } \\
\text { time }\end{array}$ \\
\hline Silo & Menampung produk & & $\checkmark$ & & $\checkmark$ & \\
\hline \multirow{2}{*}{ Bin packing } & Mengemas produk & $V$ & & & V & \\
\hline & Mengecek kontaminasi & & $V$ & & V & \\
\hline \multirow{2}{*}{$\begin{array}{l}\text { Automatic } \\
\text { Warehouse }\end{array}$} & $\begin{array}{l}\text { Mengirimkan produk packing } \\
\text { ke dalam warehouse }\end{array}$ & & V & & V & \\
\hline & $\begin{array}{l}\text { Menyusun produk packing ke } \\
\text { dalam rak warehouse }\end{array}$ & & v & & v & \\
\hline
\end{tabular}

Waste: Inapropriate process

Dari identifikasi masalah yang telah dilakukan maka usulan perbaikan yang dapat dilakukan adalah sebagai berikut:

a) Workstation Polymerization

Unnecessary Motion, Waiting \& Reject : Untuk mencegah terjadinya waste tersebut perlu diadakannya modifikasi pada area gel cutter dengan cara penambahan shower dan lubang pembuangan gel untuk dimasukan ke proses recovery. Sehingga mencegah penumpukan yang terjadi dan operator tidak perlu melakukan pekerjaan cleaning pada saat changeover dan juga pada saat proses normal berlangsung dan diharapkan dengan adanya shower tersebut tidak ada lagi gel yang stay dan terdekomposisi di area swing feeder pun dapat dicegah.

Selain menghilangkan pekerjaan yang tidak diperlukan modifikasi penambahan shower ini juga berdampak pada hilangnya waste reject dan menghilangkan waste waiting pada saat changeover berlangsung. Pada Gambar 5 dapat diketahui terjadi pengurangan waktu selama 30 menit pada saat cleaning di area gel cuter karena tidak terjadinya akumulasi gel yang terlalu banyak. 


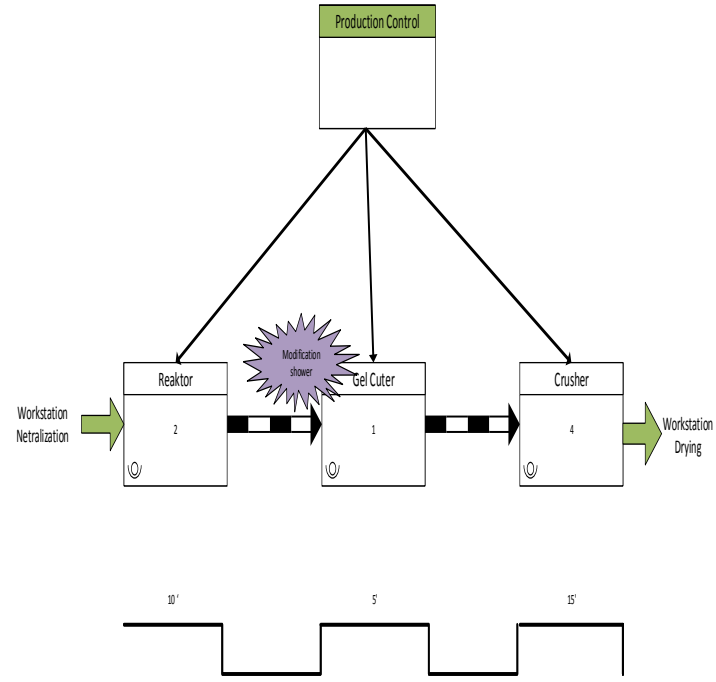

Gambar 6. Proses Cleaning Pada Workstation Polymerization

b) Workstation Drying

Waiting :

Untuk mencegah gel yang menempel pada diding reactor dibutuhkan modifikasi pada alat dengan cara penambahan silicon sheet di dinding reactor untuk mencegah gel menempel dan terdekomposisi yang menyebabkan terjadinya waste waiting pada Workstation Drying. Diharapkan dampak yang timbul setelah modifikasi dapat mencegah terjadinya gel stay pada reactor sehingga dapat menghindari terjadinya overload pada crusher dryer. Sehingga waste waiting selama $25 \mathrm{jam} /$ bulan dapat dihindari.

Reject, Waiting \& Unnecessary Motion :

Pada tabel data Waste Reject Swing feeder diketahui banyaknya reject terjadi peningkatan yang sangat besar pada bulan ke-7 (November) dikarenakan efektivitas kerja swing feeder yang telah menurun sehingga mengakibatkan reject yang sangat besar. Dengan kondisi aktual seperti ini diperlukan adanya pergantian belt pada swing feeder untuk mencegah terjadinya reject. Pergantian belt menjadikan pertimbangan untuk mencegah waste yang terjadi karena nilai biaya pergantian belt jauh lebih kecil dibandingkan dengan biaya waste reject yang terjadi. Pergantian belt dapat dilakukan pada saat produk type change dengan rincian biaya sebagai berikut:

$\begin{array}{ll}\text { Harga belt } & \text { : USD } 3833 \\ \text { Biaya pergantian } & \text { : USD } 285,7 \\ \text { Total } & \text { : USD } 4118\end{array}$

Biaya waste gel termasuk biaya transport adalah sebesar USD 122,9/ton Total reject selama 6 bulan terakhir adalah $22170 \mathrm{KG}=$ 22,17 Ton.

Jadi total biaya waste reject yang dihilangkan adalah sebesar :

$22,17 \times 122,9=$ USD 2724,7

Dengan waste reject yang berubah menjadi produk sebesar 22,17 ton maka perusahaan dapat menghasilkan USD 29929 dari hasil penjualan. Sesuai perhitungan berikut:

Harga produk : USD $1350 /$ Ton

Jumlah reject yang di reduce $: 22,17$ Ton Harga jual : USD $1350 \times 22,17$ Ton $=$ USD 29929,5

Dengan perhitungan diatas, biaya pergantian belt dapat ditutupi dengan penjualan produk yang dihasilkan sebesar jumlah reject yang dihilangkan yaitu sebesar 22,17 Ton dan dengan begitu secara tidak langsung menguntungkan perusahaan dengan mendapatkan pendapatan keuntungan sebesar USD 2724 dari hasil penjualan produk. Sehingga reject yang terjadi bisa dihilangkan / dikurangi dengan cara melakukan pergantian belt dengan masa lifetime menjadi 6 bulan.

Selain menghilangkan waste reject dampak pergantian belt juga akan berpengaruh pada waste unnecessary motion dan waste waiting terjadi pada pada saat waktu changeover. Setelah pergantian belt terdapat pengurangan waktu yang terjadi pada Workstation drying selama 15 menit pada saat changeover karena tidak terjadi penumpukan di area swing feeder dan tidak perlu dibersihkan sehingga menghilangkan waste unnecessary motion (Gambar 7)

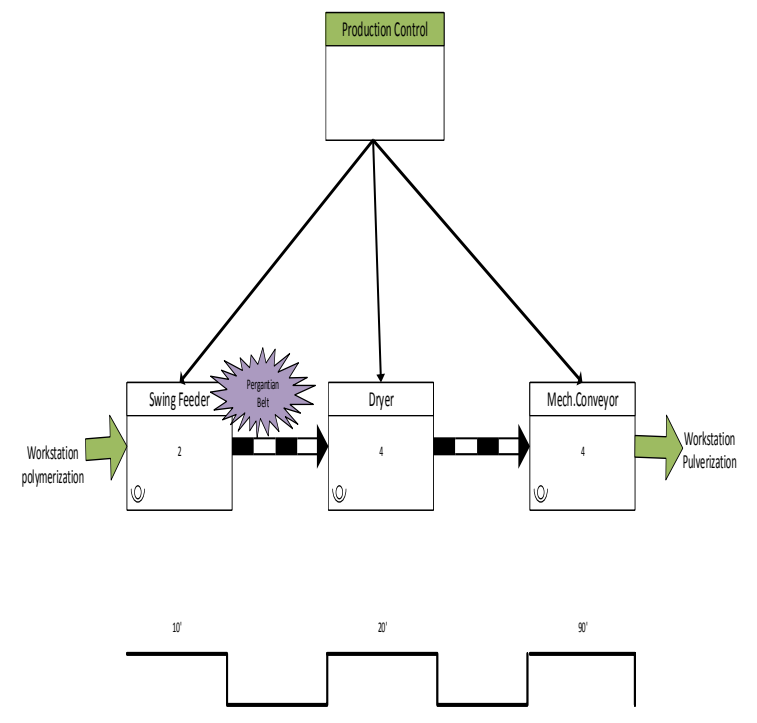

Gambar 7. Proses Cleaning Pada Workstation Drying 
c) Workstation Pulverization

Mununggu (Waiting)

Untuk mencegah terjadinya waiting pada Workstation ini diperlukan penambahan WIP agar pada saat terjadinya masalah di Workstation sebelumnya Workstation ini tidak kehabisan material untuk diproses.

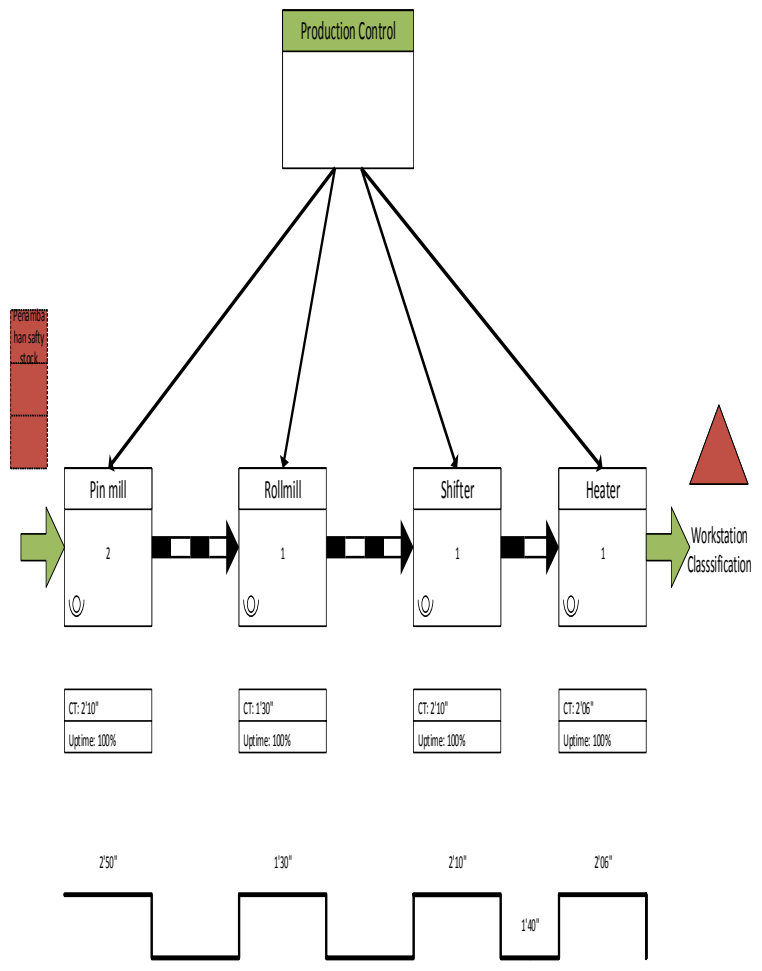

Gambar 8. Proses Produksi Pada Workstation Pulverization

Pada Value stream diatas terjadi penambahan WIP untuk mencegah terjadinya Workstation mengalami waiting yang terlalu lama apabila terjadi masalah pada Workstation sebelumnya yang membuat supply matrial menjadi terhambat.

\section{d) Workstation Classification}

\section{Transportation}

Pada Workstation classification diperlukan WIP yang berada di dekat feeder silica untuk mengurangi waste transport yang tidak diperlukan. Karena lokasi warehouse yang jauh sehingga memerlukan waktu lebih untuk operator mengambil material silica. Penambahan WIP di dekat feeder sangat membentu operator ketika pergantian countainer bag dan dapat menghilangkan waste waiting yang di sebabkan kegiatan transport selama 135 detik. Berikut perubahan layout untuk menghilangkan waste transport sehingga berdampak mengurangi waktu tunggu:

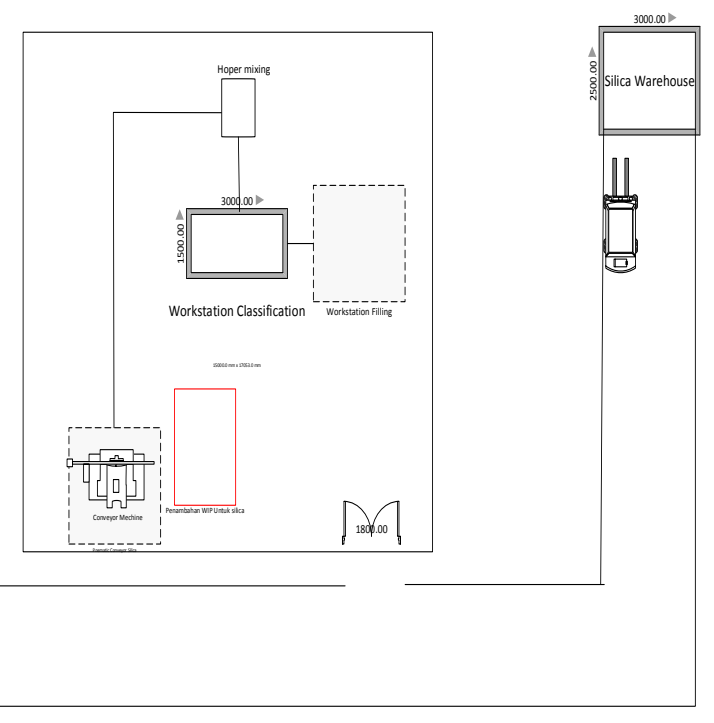

Gambar 9. Penambahan WIP Silica

Inapropriate process (Proses Yang Berlebihan)

Untuk mengurangi waste reject dilakukan perubahan metode dengan cara pengurangan jumlah powder yang di cek sebanyak $5 \mathrm{Kg}$ dengan limit contaminasi warna maksimal 5 partikel sehingga dapat mengurangi waste reject yang terjadi. Pengurangan jumlah pengecekan pada powder hanya bisa dilakukan apabila diimbangi jumlah limit maksimal kontaminasi.

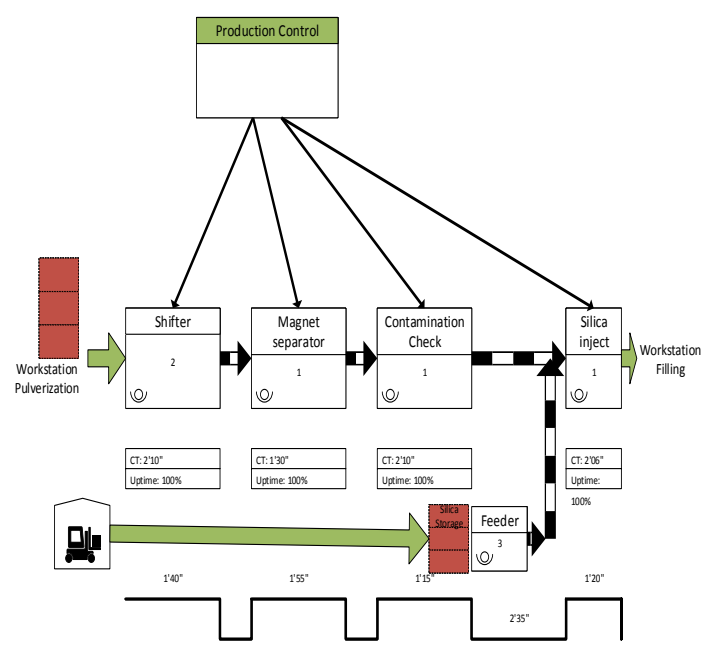

Gambar 10. Proses pada Workstation Classification

Terjadi pengurangan waktu pengecekan selama 32 detik pada proses kontaminasi check karena pengurangan jumlah pengecekan powder. Metode ini juga dengan signifikan mengurangi jumlah waste reject yang terjadi yaitu sebesar 5 $\mathrm{kg} / \mathrm{ton}$. 
e) Workstation Filling

Inapropriate process

Pada Workstation Filling sistem operasinya sudah menggunakan proses automatic warehouse segingga operator dalam Workstation ini sangat sedikit sekali mengerjakan pekerjaan secara manual oleh sebeb itu berdasarkan dari perhitungan seharusnya operator yang bekerja di Workstation ini hanya berjumlah 2 orang, sesuai dengan perhitungan berikut :

Takt time : waktu bersih yang tersedia/Demand : $466 / 1$ = 466 detik

\section{Kebutuhan pekerja : waktu baku / takt time \\ Kebutuhan pekerja $: 572.9$ detik / 466 detik $=1.2$ Operator$$
=2 \text { Operator }
$$

Dari hasil perhitungan diatas jumlah operator yang bekerja pada Workstation ini bisa dikurangi dari kondisi saat ini 3 orang menjadi 2 orang operator.

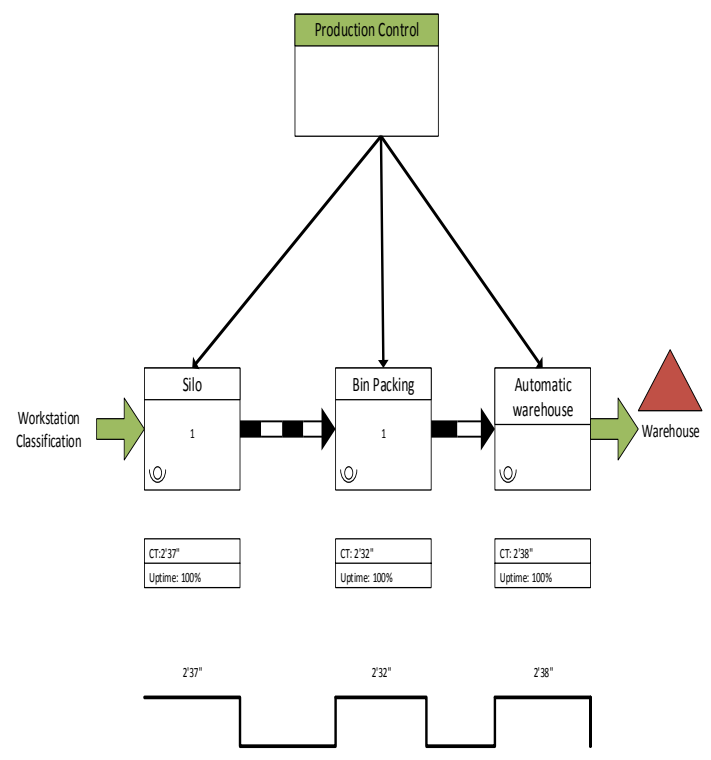

Gambar 11. Proses pada Workstation Filling

Dari hasil identifikasi waste yang telah dilakukan didapat beberapa waste yang bisa dihidari ataupun dikurangi sehingga dapat mengurangi cost pengolahan waste tersebut.

Pada pengolahan data dan usulan perbaikan sebelumnya didapatlah pebandingan pengurangan waste yang terjadi pada setiap workstation yaitu digambarkan pada Gambar 11 dan Gambar 12

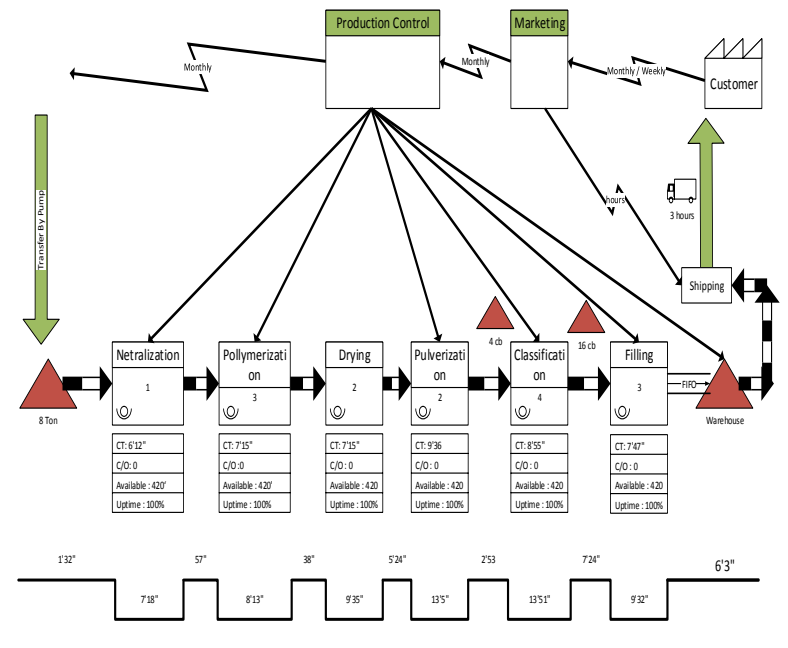

Gambar 11. Current Value stream mapping Produk Type W-343

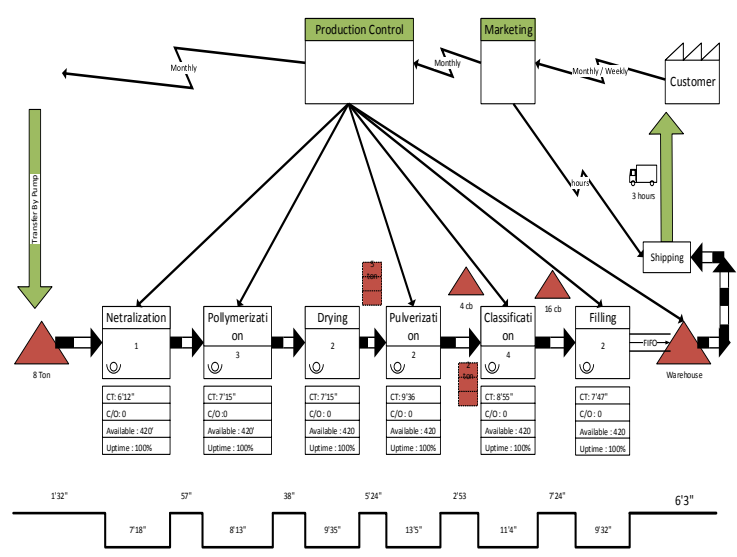

Gambar 12. Proposed Value stream mapping Produk Type W-343

Pada Gambar 13 proposed value stream mapping di atas terjadi pengurangan waktu pada proses produksi yang disebabkan karena pengurangan atau penghilangan waste yang terjadi sehingga dapat meningkatkan kecepatan proses produksi selama 167 detik atau sebesar $4,52 \%$ dari lead time proses produksi sebelumnya yaitu 3694 detik menjadi 3527 detik.:

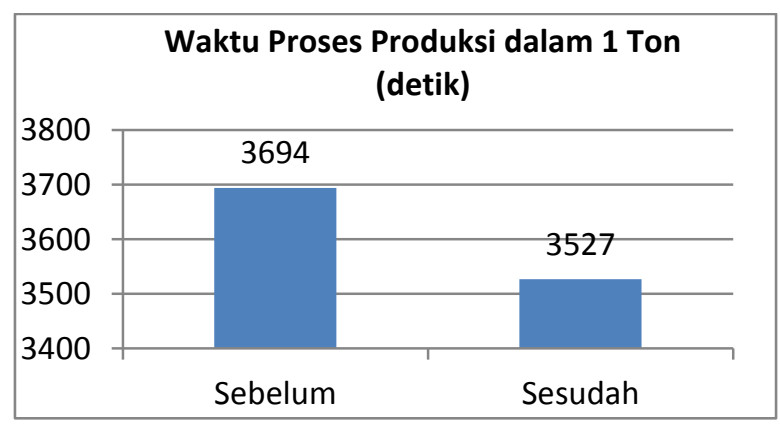

Gambar 13. Estimasi Waktu Proses Produksi 


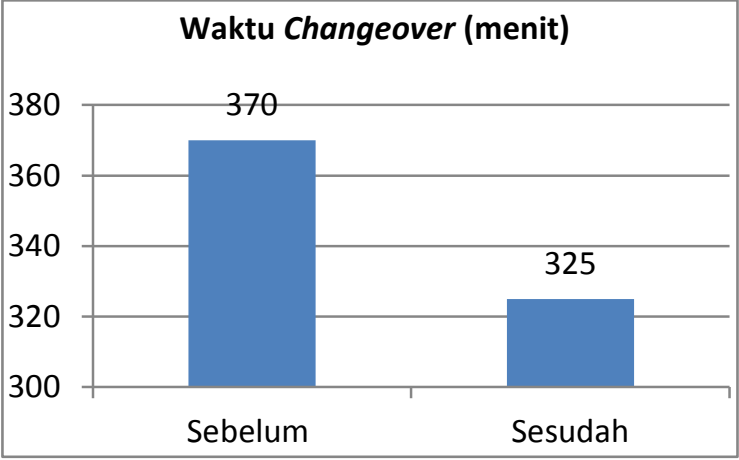

Gambar 14. Estimasi Waktu Proses Changeover

Selain terjadi pengurangan waktu changeover dan peningkatan kecepatan produksi, improvement yang dilakukan juga berdampak pada berkurangnya waste reject yang terjadi pada saat proses produksi dan changeover 9 (Gambar 15).

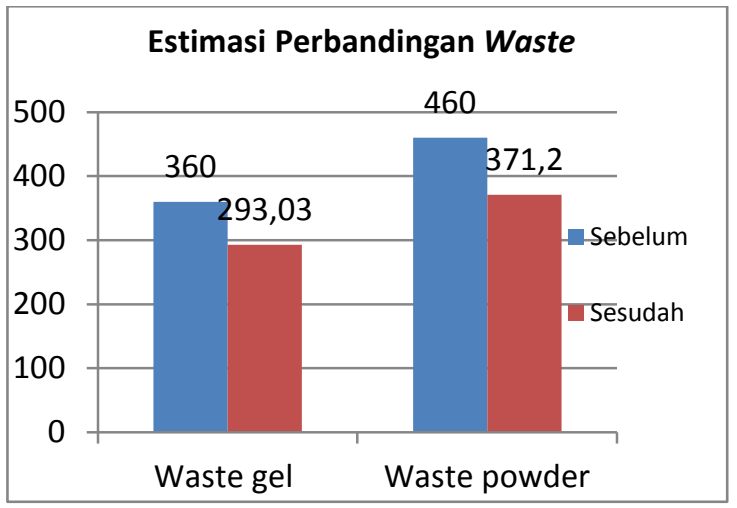

Gambar 15.Estimasi Perbandingan Waste

Pada grafik diatas terjadi pengurangan waste yang terjadi sebesar 66,97 Ton/tahun atau $18,6 \%$ pada waste gel dan 88,8 ton/tahun atau $19,3 \%$ pada waste powder, dengan berkurangnya waste yang terjadi pada perusahaan otomatis membuat pengurangan biaya pengolahan limbah yang dihasilkan dalam 1 tahun dapat dikurangi sebesar USD $15.129,8 /$ tahun.

\section{KESIMPULAN}

Berdasarkan data produksi yang diperoleh untuk produk Super Absorbent Polymer diketahui jumlah produksi pada tahun 2016 adalah sebesar 85770 MT dengan target produksi sebesar 87300 MT. Berdasarkan data yang ada jumlah waste reject yang terjadi sebesar 820 ton/ tahun. Hal ini tentunya menjadi sebuah kerugian yang sangat besar apabila tidak ditangani sebab semakin banyak produk yang gagal dalam proses produksi dan banyaknya waste yang terjadi tentunya mengakibatkan pembengkakan biaya produksi. Jenis-jenis waste yang terjadi pada Workstation di lantai produsi ada beberapa macam yaitu unnecessary motion, waiting, reject, transportation dan inpropriate process. Dan demi menaikan produktivitas diberikan usulan usulan yang dapat mengurangi atau bahkan menghilangkan waste-waste tersebut.

Berdasarkan data yang diolah menjadi usulan terjadi pengurangi waste pada tiap workstation dengan total pengurangan waste yang terjadi sebesar 66,97 Ton/tahun atau 18,6\% pada waste gel dan 88,8 ton/tahun atau $19,3 \%$ pada waste powder dan terjadi pengurangan waktu proses changeover selama 45 menit atau $12,16 \%$ dari total waktu changeover sebelum improvement selain itu juga terjadi peningkatan kecepatan proses produksi selama 2 menit 47 detik atau sebesar $4,52 \%$ dari lead time proses produksi sebelumnya yaitu 61 menit 34 detik menjadi 58 menit 47 detik. Berikut rincian pengurangan waste dari tiap workstation: Workstation polymerization: terjadi pengurangan waktu sebesar $58 \%$ pada saat changeover dan $300 \mathrm{~kg}$ atau $100 \%$ reject yang terjadi pada Workstation ini dapat dihilangkan, Workstation dryer: terjadi pengurangan reject sebesar $99,4 \%$ pada Workstation ini dan terjadi pengurangan waktu changeover sebesar $18.5 \%$, Workstation pulverization : terjadi penghilangan waste waiting sebesar $100 \%$, Workstation classification : terjadi pengurangan waktu sebesar $16,2 \%$ pada proses produksi dan pengurangan $50 \%$ waste reject yang terjadi pada Workstation ini, dan Workstation filling : terjadi pengurangan jumlah pekerja sebanyak 1 orang atau $33,3 \%$ dari total pekerja yang bekerja di Workstation ini.

Berdasarkan data yang diolah, prioritas perbaikan yang perlu dilakukan oleh PT. Nippon Shokubai Indonesia untuk menekan atau mengurangi jumlah waste yang terjadi di dalam produksi dapat dilakukan dengan mengurutkan persentase terjadinya waste tertinggi berturutturut yaitu Workstation polymerization dengan $100 \%$ waste reject dapat dihilangkan, Workstation dryer sebesar $99.4 \%$, Workstation polymerization sebesar $58 \%$ waste waiting, Workstation classification sebesar $50 \%$ dan Workstation filling sebesar 33.3\%.

\section{DAFTAR PUSTAKA}

Forrester, R. (1995). Implications of lean manufacturing for human resource strategy. Work Study, 44(3), 20-24.

Gaspersz, V. (2007). Lean Six Sigma. Jakarta: Gramedia Pustaka Utama.

Kodradi, Y., Soewignyo, P., \& Rusdiansyah, A. 
Jurnal INTECH Teknik Industri Universitas Serang Raya Vol 4 No 1 Juni 2018, 23-32

p-ISSN 2407-781x

(2008). Analisis Beban Kerja Dalam Rangka Restrukturisasi Organisasi di PT Petrokimia Gresik. In Prosiding Seminar Nasional Manajemen Teknologi VIII.

Rother, M., \& Shook, J. (2003). Learning to see: value stream mapping to add value and eliminate muda. Lean Enterprise Institute 